\title{
CX3CR1 Polymorphisms Are Associated with Atopy but Not Asthma in German Children
}

\author{
Martin Depner $^{\mathrm{a}} \quad$ Michael S.D. Kormann ${ }^{\mathrm{a}} \quad$ Norman Klopp $^{\mathrm{b}}$ Thomas Illig $^{\mathrm{b}}$ \\ Christian Vogelberg $^{c}$ Stephan K. Weiland ${ }^{d}$ Erika von Mutius $^{a}$ \\ Christophe Combadière $^{\mathrm{e}}$ Michael Kabesch $^{\mathrm{a}}$ \\ aUniversity Children's Hospital, Ludwig Maximilians University Munich, Munich, ${ }^{b}$ Institute of Epidemiology, \\ GSF-Research Centre for Environment and Health, Neuherberg, 'University Children's Hospital, \\ Dresden University, Dresden, and d Institute of Epidemiology, Ulm University, Ulm, Germany; eINSERM U543, \\ Hôpital Pitié-Salpêtrière, Paris, France
}

\section{Key Words}

Asthma $\cdot$ Atopy $\cdot$ Chemokine $\cdot$ Polymorphism $\cdot$ CX3CR1 atopy but not asthma in German children. Potentially, other factors such as environmental effects may modify the role of CX3CR1 polymorphisms.

Copyright $\odot 2007$ S. Karger AG, Basel

\begin{abstract}
Chemokines and their receptors are involved in many aspects of immunity. Chemokine CX3CL1, acting via its receptor CX3CR1, regulates monocyte migration and macrophage differentiation as well as $\mathrm{T}$ cell-dependent inflammation. Two common, nonsynonymous polymorphisms in $C X 3 C R 1$ have previously been shown to alter the function of the CX3CL1/CX3CR1 pathway and were suggested to modify the risk for asthma. Using matrix-assisted laser desorption/ionization time-of-flight technology, we genotyped polymorphisms Val249lle and Thr280Met in a cross-sectional population of German children from Munich $(n=1,159)$ and Dresden ( $n=1,940)$. For 249 lle an odds ratio of 0.77 (95\% confidence interval $0.63-0.96 ; p=0.017$ ) and for 280Met an odds ratio of 0.71 (95\% confidence interval $0.56-0.89 ; p=0.004$ ) were found with atopy in Dresden but not in Munich. Neither polymorphism was associated with asthma. Thus, amino acid changes in CX3CR1 may influence the development of
\end{abstract}

\section{Introduction}

Interleukins and chemokines are involved in the induction and perpetuation of allergic immune responses. The chemokine CX3CL1 (fractalkine) which binds exclusively to CX3CR1, a 7-transmembrane high-affinity receptor, is expressed by endothelium and epithelium. It is a potent mediator of monocyte migration and macrophage differentiation and CX3CR1 knockout mice show a decrease in monocyte and macrophage recruitment [1]. The CX3CL1/ CX3CR1 pathway is also important in Th1 and natural killer cell responses, as these cell types express high levels of CX3CR1 and respond to CX3CL1, while Th2-type cells express low levels of CX3CR1 and do not readily respond to CX3CL1 [2].

\section{KARGER}

Fax +4161306 1234 E-Mail karger@karger.ch www.karger.com (c) 2007 S. Karger AG, Basel

$1018-2438 / 07 / 1441-0091 \$ 23.50 / 0$

Accessible online at:

www.karger.com/iaa
Correspondence to: Dr. Michael Kabesch

University Children's Hospital, Ludwig Maximilians University Munich

Lindwurmstrasse 4, DE-80337 München (Germany)

Tel. +49 895160 2792, Fax +49 8951604764

E-Mail Michael.Kabesch@med.uni-muenchen.de 
Table 1. Description of the investigated CX3CR1 single nucleotide polymorphisms and primers used for matrix-assisted laser desorption/ionization time-of-flight mass spectrometry

\begin{tabular}{|c|c|c|c|c|c|c|}
\hline SNP & rs No. & Alleles & $\begin{array}{l}\mathrm{p} \text { value (test } \\
\text { for deviation } \\
\text { of HWE) }\end{array}$ & $\begin{array}{l}\text { Minor allele } \\
\text { frequency }\end{array}$ & PCR primer & Extension primer \\
\hline $\begin{array}{l}\text { CX3CR1 } \\
\text { Val249Ile }\end{array}$ & rs3732379 & $\mathrm{G} / \mathrm{A}$ & 0.622 & 0.27 & $\begin{array}{l}\text { 1st ACGTTGGATGTAGAGCTTAAGCGTCTCCAG } \\
\text { 2nd ACGTTGGATGTGATCCTTCTGGTGGTCATC }\end{array}$ & $\begin{array}{l}\text { CTTCTGGACACC- } \\
\text { CTACAAC }\end{array}$ \\
\hline $\begin{array}{l}\text { CX3CR1 } \\
\text { Thr280Met }\end{array}$ & rs3732378 & $\mathrm{C} / \mathrm{T}$ & 0.605 & 0.17 & $\begin{array}{l}\text { 1st ACGTTGGATGGATGAGAGGATTCAGGCAAC } \\
\text { 2nd ACGTTGGATGACATGAGGAAGGATCTGAGG }\end{array}$ & $\begin{array}{l}\text { CCTCAGTGTGAC- } \\
\text { TGAGA }\end{array}$ \\
\hline
\end{tabular}

$\mathrm{SNP}=$ Single nucleotide polymorphism; HWE $=$ Hardy-Weinberg equilibrium; PCR $=$ polymerase chain reaction.

Thus, it was suggested that the CX3CL1/ CX3CR1 pathway serves as an amplification circuit for polarized Th1 responses. Alternatively, CX3CR1-dependent processes may also regulate immunological tolerance and inflammation by controlling interactions of dendritic cells with pathogens [3].

In the airways, CX3CL1 is produced by smooth muscle cells. In asthmatics, CX3CL1 levels are upregulated and CX3CR1 function is increased in peripheral CD4+ T lymphocytes recruited to the airways after allergen stimulation [4]. In contrast, baseline expression of CX3CR1 is decreased in the airways of asthmatics compared to healthy controls [5]. In the case of bronchial inflammation, CX3CL1 levels seem to correlate positively with mononuclear cell counts in bronchoalveolar lavage [6].

Common CX3CR1 polymorphisms leading to amino acid changes (Val249Ile and Thr280Met) were previously identified and result in decreased receptor expression, reduced receptor function and diminished ligand affinity [7]. Although both variants responded similarly to soluble CX3CL1 [8], 249Ile was also associated with enhanced adhesiveness [9]. These functional polymorphisms were recently proposed to protect from asthma, while no effect on atopy was found [10]. We investigated the role of both functional polymorphisms in atopy and asthma in 2 cross-sectional German populations of 9- to 11-year-old children from West (Munich $n=1,159$ ) and East Germany (Dresden $n=1,940)$.

\section{Material and Methods}

As described previously [11], 3,099 German children (9-11 years) recruited from Munich and Dresden in the cross-sectional International Study on Asthma and Allergy in Childhood (ISAAC II) were phenotyped for a doctor's diagnosis of asthma, hay fever and atopic dermatitis by questionnaire, for atopy by skin prick testing, as well as total and specific serum IgE tests against aero- allergens (Sx1) and food allergens (Fx5) (Pharmacia, Freiburg, Germany). Informed written consent was obtained from the parents of children included in the study. All study methods were approved by the local ethics committees.

Genomic DNA was extracted from whole blood by a standard salting out method and for genotyping, matrix-assisted laser desorption/ionization time-of-flight mass spectrometry was applied as described in detail elsewhere [12] using primers (Sequenom, San Diego, Calif., USA) shown in table 1.

Deviation from Hardy-Weinberg equilibrium was analyzed with $\chi^{2}$ tests. Association between single nucleotide polymorphisms and dichotomous outcomes were evaluated using $\chi^{2}$ tests in a dominant model of the rare allele. All statistical tests were two-sided and a nominal level of significance $(\alpha=0.05)$ was used. Calculations were carried out with SAS (version 9.1.3) and SAS/ Genetics.

\section{Results}

Genotyping was successful in $97.8 \%$ and $98.5 \%$ of samples for Val249Ile and Thr280Met, respectively, and both single nucleotide polymorphisms did not deviate from Hardy-Weinberg equilibrium (table 1). In the Dresden population, 249Ile and 280Met significantly decreased the risk to develop atopy (table 2). In addition, carriers of the $280 \mathrm{Met}$ allele were less likely to show significantly elevated serum IgE levels (above the 66th and 90th percentile of the German reference population of this age, equivalent to 115 and $457 \mathrm{IU} / \mathrm{ml}$, respectively). When the association between polymorphisms and increased specific serum IgE against either inhalant (Sx1) or food allergens (Fx5) was analyzed, 249Ile and 280Met were protective against sensitization to aeroallergens but not food allergens. However, no such effects were observed in the $\mathrm{Mu}-$ nich population. In addition, no association was found between polymorphisms in CX3CR1 and the development of atopic dermatitis, hay fever and asthma neither in Dresden nor in Munich (data not shown). 
Table 2. Association between $C X 3 C R 1$ polymorphisms and atopy defined by skin prick test, and total and specific serum IgE measurements in populations from Munich and Dresden

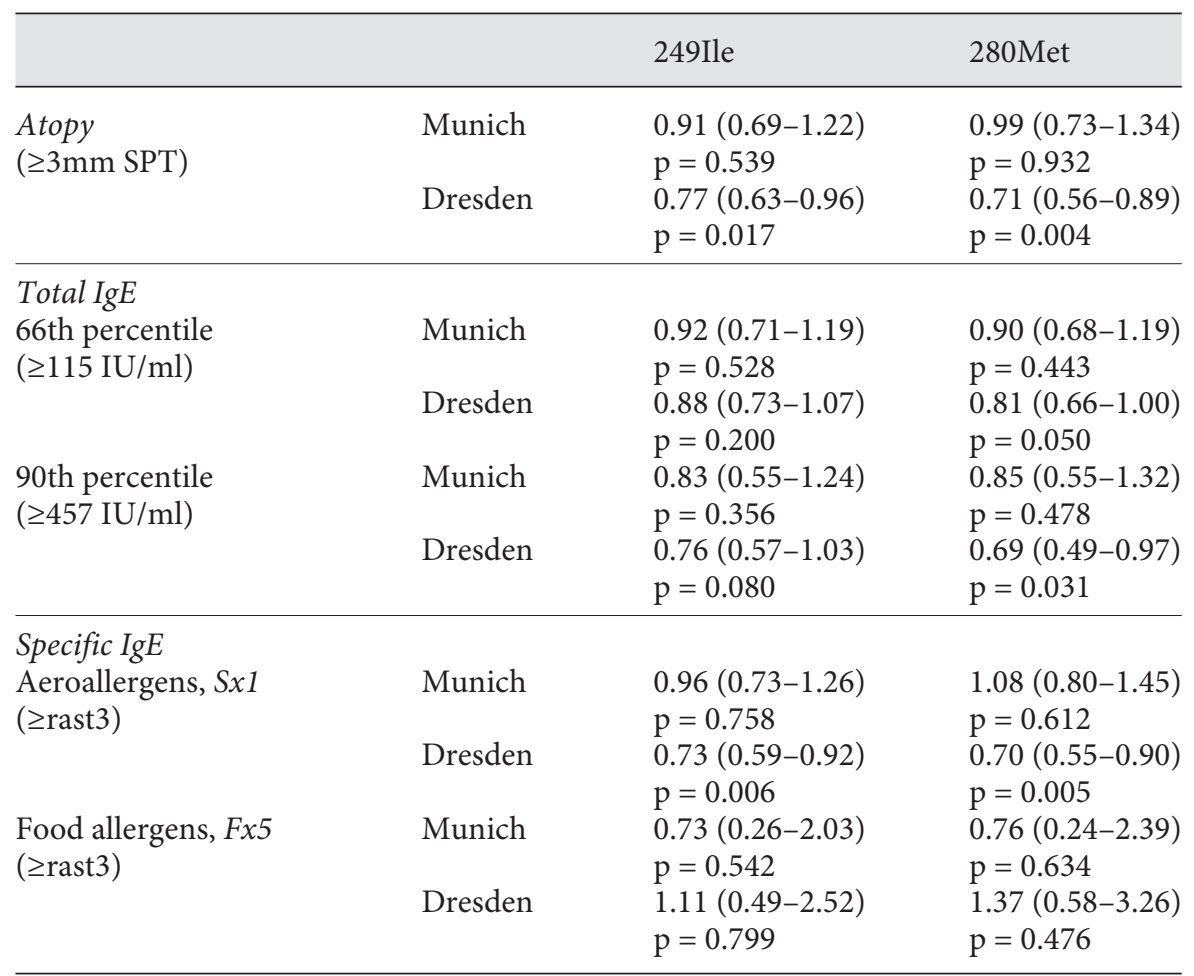

Odds ratios and 95\% confidence intervals in parentheses are shown for the association between CX3CR1 polymorphisms and atopy measured by skin prick test, total serum IgE percentiles and specific serum IgE against inhalative ( $(x \times 1)$ and food (Fx5) allergens in Munich $(n=1,159)$ and Dresden $(n=1,940)$. In Dresden, 25.4\% $(n=493)$ of the children showed a positive reaction in skin prick testing and $24.5 \%(\mathrm{n}=284)$ in $\mathrm{Mu}-$ nich.

\section{Discussion}

An inverse association between the CX3CR1 polymorphisms 249Ile and 280Met and atopic sensitization was only present in children from Dresden. This association could be spurious but could alternatively be explained by CX3CR1 interactions with different environmental factors in both study populations. Notably, children from Dresden spent their first 3 years of life in the former German Democratic Republic, exposed to very different lifestyle factors (e.g. higher number of siblings, early day care, different outdoor pollutants, pet keeping) which were previously associated with the development of or the protection against asthma and atopy $[11,13]$. These environmental effects may act through gene-by-environment interactions as shown previously for other genes [14]. The results of this study may only be a fist hint towards a possible role of CX3CR1 polymorphisms in such interactions, which have not yet been elucidated further.
No protective effect was observed for asthma, which could have been expected based on previous association studies [10]. Thus, the discrepancy in results between atopy and asthma observed with CX3CR1 polymorphisms may reflect some differences in pathomechanisms between asthma and atopy, and the functional impact of CX3CR1 variants in atopy may involve a delicate balance between excessive adhesion and chemotaxis. Accordingly, our results may indicate that CX3CR1 is more involved in immunological mechanisms of atopic sensitization than the induction of a lung-specific atopic inflammation.

This study did not aim at performing a systematic and comprehensive study of the whole CX3CR1 gene locus. Rather, amino acid changes leading to clearly characterized functional changes which were previously reported to be involved in other diseases were studied for their role in atopy and atopic diseases. Thus, it cannot be excluded that further polymorphisms in and around the CX3CR1 
gene may contribute to the development of atopic diseases as suggested by others [10].

In conclusion, this study suggests that $C X 3 C R 1$ polymorphisms show variable associations with atopy and asthma in different populations. If these discrepancies are attributable to chance only or if these inconsistencies are due to cofactors such as gene-by-gene or gene-by-environment interactions, needs further evaluation.

\section{Acknowledgements}

This work was founded by the German Ministry of Education and Research (BMBF)/National Genome Research Network (NGFN) research grants NGFN 01GS 0429 and NGFN IES08T03.

\section{References}

1 Combadiere C, Potteaux S, Gao JL, Esposito B, Casanova S, Lee EJ, Debre P, Tedgui A, Murphy PM, Mallat Z: Decreased atherosclerotic lesion formation in CX3CR1/apolipoprotein E double knockout mice. Circulation 2003;107:1009-1016.

2 Fraticelli P, Sironi M, Bianchi G, D’Ambrosio D, Albanesi C, Stoppacciaro A, Chieppa M, Allavena P, Ruco L, Girolomoni G, Sinigaglia F, Vecchi A, Mantovani A: Fractalkine (CX3CL1) as an amplification circuit of polarized Th1 responses. J Clin Invest 2001; 107:1173-1181.

3 Niess JH, Brand S, Gu X, Landsman L, Jung S, McCormick BA, Vyas JM, Boes M, Ploegh HL, Fox JG, Littman DR, Reinecker HC: CX3CR1-mediated dendritic cell access to the intestinal lumen and bacterial clearance. Science 2005; 307:254-258.

4 Rimaniol AC, Till SJ, Garcia G, Capel F, Godot V, Balabanian K, Durand-Gasselin I, Varga EM, Simonneau G, Emilie D, Durham SR, Humbert M, Foussat A, CoulombL'Hermine A, Gosling J, Krzysiek R, Schall T, Balian A, Richard Y, Galanaud P, McDermott DH, Halcox JP, Schenke WH, Waclawiw MA, Merrell MN, Epstein N, Quyyumi AA, Murphy PM, Moatti D, Faure S, Fumeron F, Amara Mel W, Seknadji P, Debre P, Aumont MC, de Prost D, Combadiere C: The CX3C chemokine fractalkine in allergic asthma and rhinitis. J Allergy Clin Immunol 2003; 112:1139-1146.
5 Laprise C, Sladek R, Ponton A, Bernier MC, Hudson TJ, Laviolette M: Functional classes of bronchial mucosa genes that are differentially expressed in asthma. BMC Genomics 2004;5:21.

6 Fujimoto K, Imaizumi T, Yoshida $\mathrm{H}$, Takanashi S, Okumura K, Satoh K: Interferon- $\gamma$ stimulates fractalkine expression in human bronchial epithelial cells and regulates mononuclear cell adherence. Am J Respir Cell Mol Biol 2001;25:233-238.

7 Moatti D, Faure S, Fumeron F, Amara Mel W, Seknadji P, McDermott DH, Debre P, Aumont MC, Murphy PM, de Prost D, Combadiere C: Polymorphism in the fractalkine receptor CX3CR1 as a genetic risk factor for coronary artery disease. Blood 2001;97: 1925-1928.

8 Davis CN, Harrison JK: Proline 326 in the C terminus of murine CX3CR1 prevents Gprotein and phosphatidylinositol 3-kinasedependent stimulation of Akt and extracellular signal-regulated kinase in Chinese hamster ovary cells. J Pharmacol Exp Ther 2006;316:356-363.
9 Daoudi M, Lavergne E, Garin A, Tarantino N, Debre P, Pincet F, Combadiere C, Deterre $P$ : Enhanced adhesive capacities of the naturally occurring Ile249-Met280 variant of the chemokine receptor CX3CR1. J Biol Chem 2004;279:19649-19657.

10 Tremblay K, Lemire M, Provost V, Pastinen T, Renaud Y, Sandford AJ, Laviolette M, Hudson TJ, Laprise C: Association study between the CX3CR1 gene and asthma. Genes Immun 2006;7:632-639.

11 Weiland SK, von Mutius E, Hirsch T, Duhme $\mathrm{H}$, Fritzsch C, Werner B, Husing A, Stender M, Renz H, Leupold W, Keil U: Prevalence of respiratory and atopic disorders among children in the East and West of Germany five years after unification. Eur Respir J 1999;14: 862-870.

12 Kormann MS, Carr D, Klopp N, Illig T, Leupold W, Fritzsch C, Weiland SK, von $\mathrm{Mu}-$ tius E, Kabesch M: G-Protein-coupled receptor polymorphisms are associated with asthma in a large German population. Am J Respir Crit Care Med 2005;171:1358-1362.

13 Kramer U, Heinrich J, Wjst M, Wichmann HE: Age of entry to day nursery and allergy in later childhood. Lancet 1999;353:450454

14 Simpson A, John SL, Jury F, Niven R, Woodcock A, Ollier WE, Custovic A: Endotoxin exposure, CD14, and allergic disease: an interaction between genes and the environment. Am J Respir Crit Care Med 2006;174: 386-392. 